\title{
Nitrogen Uptake of Wheat Cultivars As Influenced By Urease Inhibitor Application Stages and Nitrogen Levels
}

\author{
Amir Zaman Khan, Aman Khan, Shahzad Ali, Shad Khan Khalil, Amanullah Jan and Muhammad Afzal \\ Department of Agronomy, The University of Agriculture, Peshawar, Pakistan \\ Department of Soil Science, The University of Agriculture, Peshawar, Pakistan \\ Corresponding author's email: shahzadali320@aup.edu.pk
}

\begin{abstract}
The performance of wheat cultivars (Triticum aestivum L.) was evaluated using various nitrogen levels and urease inhibitor application stages at New Developmental Farm of The University Agriculture, Peshawar, Pakistan during winter 2012-13. The field experiment was layout in randomized complete block design with split plot arrangement having four replications. Four nitrogen levels $\left(0,60,120\right.$ and $\left.150 \mathrm{~kg} \mathrm{ha}^{-1}\right)$ and urease inhibitor stages (100\% sowing stage, $50 \%$ sowing stage $+50 \%$ booting stage and $100 \%$ booting stage) were allotted to main plots, while wheat cultivars (Siran and Atta-Habib) were allotted to sub plots. Application of urease inhibitor $100 \%$ at sowing stage had maximum nitrogen uptake in root $\left(11.40 \mathrm{~g} \mathrm{~kg}^{-1}\right)$, nitrogen uptake in stem $\left(9.95 \mathrm{~g} \mathrm{~kg}^{-1}\right)$, nitrogen uptake in leaves $\left(15.06 \mathrm{~g} \mathrm{~kg}^{-1}\right)$ and nitrogen uptake in grain $\left(32.68 \mathrm{~g} \mathrm{~kg}^{-1}\right)$ as compared with urease application $100 \%$ at booting stage but maximum nitrogen in soil $\left(7.39 \mathrm{~g} \mathrm{~kg}^{-1}\right)$ was recorded when urea coated with urease inhibitor $100 \%$ at booting stage. Plots treated with $120 \mathrm{~kg} \mathrm{~N} \mathrm{ha}^{-1}$ produced maximum nitrogen uptake in root $\left(9.90 \mathrm{~g} \mathrm{~kg}^{-1}\right)$, nitrogen uptake in stem $\left(8.94 \mathrm{~g} \mathrm{~kg}^{-}\right.$ $\left.{ }^{1}\right)$, nitrogen uptake in leaves $\left(14.03 \mathrm{~g} \mathrm{~kg}^{-1}\right)$ and nitrogen uptake in grain $\left(29.78 \mathrm{~g} \mathrm{~kg}^{-1}\right)$ as compared with control plots while maximum nitrogen in soil $\left(6.90 \mathrm{~g} \mathrm{~kg}^{-1}\right)$ was recorded when plots treated with $150 \mathrm{~kg} \mathrm{~N}$ $\mathrm{ha}^{-1}$. Wheat cultivar Siran had significantly produced maximum nitrogen uptake in root $\left(7.04 \mathrm{~g} \mathrm{~kg}^{-1}\right)$, nitrogen uptake in stem $\left(5.86 \mathrm{~g} \mathrm{~kg}^{-1}\right)$, nitrogen uptake in leaves $\left(11.62 \mathrm{~g} \mathrm{~kg}^{-1}\right)$ and nitrogen uptake in grain (25.15 $\mathrm{g} \mathrm{kg}^{-1}$ ) as compared to Atta-Habib. It was concluded from this study that cultivar Siran treated with $120 \mathrm{~kg} \mathrm{~N} \mathrm{ha}^{-1}$ and coated urea with urease inhibitor $100 \%$ at sowing stage for improved nitrogen uptake in root, stem, leaves and grain and thus, is recommended for general practice in agro-climatic conditions of Peshawar valley.
\end{abstract}

Key Words: $\quad$ Wheat (Triticum aestivum L.), Urease inhibitor application stages, Nitrogen levels, Wheat cultivars, Nitrogen uptake

\section{Introduction}

Wheat (Triticum aestivum L.) a member of family Gramineae, is a world first grain crop. Wheat is generally cultivated for grain production. In countries like Argentina, Australia, Morocco, Syria and Uruguay wheat exceeds from all other crops both in area and production [1]. It is also grown as fodder crop for livestock due to it palatability, higher crude protein and digestibility compared to other fodder crop [2]. In Pakistan the total area occupied by wheat was 8900.7 hectares, which produced 25214 tones with average yield of $2833 \mathrm{~kg} \mathrm{ha}^{-1}$ where as in Khyber Pakhtunkhwa, it was grown of on an area of 725 hectares produced 1156 tones with an average yield of $1595 \mathrm{~kg} \mathrm{ha}^{-1}$ [3]. A major pathway by which Nitrogen is lost from agricultural settings is through $\mathrm{NH}_{3}$ Volatilization. [4] estimated that $65 \%$ of the global $\mathrm{NH}_{3}$ flux to the atmosphere is emitted from agricultural systems, including animal production and the use of synthetic Fertilizers [5]. urea is an organic fertilizer that needs to be hydrolyzed by the enzyme urease inhibitor before $\mathrm{NH}_{3}$ can be volatilized. This hydrolysis of urea can be rapid under certain environmental conditions [6]. The prevalent concern over $\mathrm{N}$ fertilizer losses has led to various researches that have revealed the role of Humic Acids (HA), Fulvic Acids (FA) and Triple Super-Phosphate (TSP) as amendments to delay hydrolysis of urea fertilizer, thereby controlling ammonia volatilization. Low $\mathrm{pH}$ and high total acidity (Cation Exchange Capacity, CEC) associated with HA and FA enable them to inhibit urease inhibitor activity, retain ammonium, delay hydrolysis of urea, thereby reducing ammonia volatilization [7].

Timing of Nitrogen application had a significant role on the $\mathrm{N}$ indices and can help in Reducing $\mathrm{N}$ losses. [8] reported that $\mathrm{N}$ losses could be minimized if $\mathrm{N}$ application is made before the onset of stem elongation. When $\mathrm{N}$ was applied at first node stage, the total $\mathrm{N}$ uptake was greater than at planting time [9]. Similarly, [10] reported that early application of $\mathrm{N}$ at planting and tillering had lower $\mathrm{N}$ fertilizer uptake than later application (shooting) in wheat. Split and latter 
application of $\mathrm{N}$ increased NUE through avoiding unnecessary vegetative growth and losses of $\mathrm{N}$ [11]. Between the different management options (avoiding heavy $\mathrm{N}$ application rates, applying $\mathrm{N}$ fertilizer at appropriate time, splitting $\mathrm{N}$ applications, using slow release fertilizer, or coating $\mathrm{N}$ fertilizers with polymers or elemental $\mathrm{S}$ ), adding urease inhibitor to urea may have the greatest potential to reduce $\mathrm{N}$ losses and enhance its $\mathrm{N}$ efficiency [8]. Nitrogen application promotes tillering and leaf growth, whereas late application prolongs leaf area duration and expansion [12]. Urease inhibitor catalyses urea hydrolysis thus making urea-N available to be assimilated into organic compounds [13]. Keeping in view the above constraints this experiment was conducted to determined best urease inhibitor stage, nitrogen level and wheat cultivar suitable under agroclimatic condition of Peshawar.

\section{Materials and Methods}

A field experiment was conducted to investigate the effects of nitrogen levels and urease inhibitor application stages on nitrogen uptake of wheat cultivars. Therefore a filed trail was carried out at New Developmental Farm of The University of Agriculture, Peshawar, Pakistan during winter 2012-13. The experimental farm is located at $34.01^{\circ} \mathrm{N}$ latitude, $71.35^{\circ} \mathrm{E}$ longitude at an altitude of $350 \mathrm{~m}$ above sea level. The farm soil was silty clay loam and was deficient in available nitrogen with soil organic matter contents were less than $1 \%$ [14]. The experiment was carried out in randomized complete block design with split plot arrangement having four replications. Four nitrogen levels $(0,60,120$ and $\left.150 \mathrm{~kg} \mathrm{ha}^{-1}\right)$ and urease inhibitor stages $(100 \%$ sowing stage, $50 \%$ sowing stage $+50 \%$ booting stage and $100 \%$ booting stage) were allotted to main plots, while wheat cultivars (Siran and Atta-Habib) were allotted to sub plots. A subplot size of $5 \times 3 \mathrm{~m}$ was used. Each sub plot was consisted of 10 rows having $30 \mathrm{~cm}$ row-torow distance. Phosphorus as $\mathrm{P}_{2} \mathrm{O}_{5}$ was applied at the rate of $90 \mathrm{~kg} \mathrm{ha}^{-1}$, and $\mathrm{K}_{2} \mathrm{O}$ at $60 \mathrm{~kg} \mathrm{ha}^{-1}$ as basal dose at sowing time. Seed were sown at rate of $100 \mathrm{~kg} \mathrm{ha}^{-1}$. The crop was sown in November 2012 and harvested in May 2013. Recommended cultural practices were followed throughout the growing period. The crop was irrigated with canal water when needed. The crop was harvested at maturity and data was recorded on nitrogen uptake in roots, stem, leaves, grain and nitrogen in soil.

\section{Laboratory Analysis}

Biomass, grain and soil samples analyzed for total $\mathrm{N}$ content using a micro-Kjeldahl digestion with Sulfuric acid [15].

\section{Statistical Analysis}

Data were analyzed using the statistical package MSTAT-C [16] and the significant differences among the treatments were determined using least significant difference (LSD) test at 5\% level of probability.

\section{Results and Discussion \\ $N$ uptake in roots $\left(\mathrm{g}^{-1}\right)$}

Mean value of nitrogen uptake in roots given in table 1 showed that increasing nitrogen levels significantly increase $\mathrm{N}$ uptake in roots. Plots treated with $120 \mathrm{~kg} \mathrm{~N}^{-1}$ uptake more nitrogen in roots $\left(9.90 \mathrm{~g} \mathrm{~kg}^{-1}\right)$ while less $\mathrm{N}$ uptake in roots (4.54 $\left.\mathrm{g} \mathrm{kg}^{-1}\right)$ were recorded in control plots. This finding agrees with the reports of [17] who reported that plots received $130 \mathrm{~kg} \mathrm{~N} \mathrm{ha}{ }^{-1}$ increased $\mathrm{N}$ uptake in roots $(46 \%)$ as compared with control plots further increase in nitrogen slightly reduction in $\mathrm{N}$ uptake occur. Urea coated with urease inhibitor $100 \%$ at sowing time uptake more nitrogen in roots $\left(11.40 \mathrm{~g} \mathrm{~kg}^{-1}\right)$ while less $\mathrm{N}$ uptake in roots $\left(7.07 \mathrm{~g} \mathrm{~kg}^{-1}\right)$ was recorded when urea coated with urease inhibitor $100 \%$ at booting stage. These results agree with those of [18] who studied that urea coated with urease inhibitor $100 \%$ at sowing stage minimized volatilization of nitrogen and improved nitrogen available to crop as a result roots uptake maximum $\mathrm{N}$ as compared urea coated with urease inhibitor $100 \%$ at booting stage. Cultivar Siran uptake more $\mathrm{N}$ in roots $\left(7.04 \mathrm{~g} \mathrm{~kg}^{-1}\right)$ as compared to cultivar Atta-Habib which uptake less $\mathrm{N}$ in roots $\left(6.82 \mathrm{~g} \mathrm{~kg}^{-1}\right)$. These results agree with those of [1] who reported that the difference in uptake of $\mathrm{N}$ in roots among the cultivars might be due to genetic makeup and nitrogen uptake ability.

\section{$\mathrm{N}$ uptake in stem $\left(\mathrm{g} \mathrm{kg}^{-1}\right)$}

Mean values of the data indicated in table 1 that nitrogen uptake in stem was significantly affected by urease inhibitor, wheat cultivars and nitrogen levels. Increasing in nitrogen level significantly increased $\mathrm{N}$ uptake in stem was recorded. Plots treated with $120 \mathrm{~kg} \mathrm{~N} \mathrm{ha}^{-1}$ uptake maximum $\mathrm{N}$ in stem $\left(8.94 \mathrm{~g} \mathrm{~kg}^{-1}\right)$ while minimum $\mathrm{N}$ uptake in stem $\left(3.54 \mathrm{~g} \mathrm{~kg}^{-1}\right)$ was recorded in control plots. These results are in line with [19] who reported that nitrogen fertilizer application had significant effect on uptake of $\mathrm{N}$ in stem with increase the nitrogen level uptake of $\mathrm{N}$ increased in stem up to (43\%) if we compared with control plots. Urea coated with urease 
inhibitor $100 \%$ at sowing stage uptake maximum $\mathrm{N}$ in stem $\left(9.95 \mathrm{~g} \mathrm{~kg}^{-1}\right)$, while minimum $\mathrm{N}$ uptake in stem $\left(5.34 \mathrm{~g} \mathrm{~kg}^{-1}\right)$ was recorded when urea coated with urease inhibitor $100 \%$ at booting stage. Similar result is reported by [20] who studied that application of urease inhibitor has increased nitrogen recovery and increased uptake of $\mathrm{N}$ in stem by reducing $\mathrm{NH}_{3}$ volatilization and $\mathrm{NO}_{2}$ emission from the plant soil system when urea coated with urease inhibitor $100 \%$ at sowing stage as compared with $100 \%$ at booting stage. Cultivar Siran produced maximum $\mathrm{N}$ uptake in stem $\left(5.86 \mathrm{~g} \mathrm{~kg}^{-1}\right)$ as compared to cultivar Atta-Habib which produced minimum $\mathrm{N}$ uptake in stem $\left(5.45 \mathrm{~g} \mathrm{~kg}^{-1}\right)$. The difference among the cultivars might be due to hereditary superiority, growth rate, and higher nitrogen translocation as a result uptake of $\mathrm{N}$ to ward stem is increased.

N uptake in leaves $\left(\mathrm{g} \mathbf{k g}^{-1}\right)$

Data regarding $\mathrm{N}$ uptake in leaves given in table 1 revealed that $\mathrm{N}$ uptake in leaves increase with increasing nitrogen levels and uptake maximum $\mathrm{N}$ in leaves $\left(14.03 \mathrm{~g} \mathrm{~kg}^{-1}\right.$ ) was recorded for 120 $\mathrm{kg} \mathrm{N} \mathrm{ha}{ }^{-1}$ but statistically at par with $150 \mathrm{~kg} \mathrm{~N}$ $\mathrm{ha}^{-1}$ while minimum $\mathrm{N}$ uptake in leaves $(8.50 \mathrm{~g}$ $\mathrm{kg}^{-1}$ ) was produced in control plots. Similar results were reported by [21] who studied that plots received $130 \mathrm{~kg} \mathrm{~N}^{-1}$ increased $\mathrm{N}$ uptake in leaves $(38 \%)$ as compared with control plots further increase in nitrogen slightly reduction in $\mathrm{N}$ uptake in leaves occur. Cultivar Siran produced maximum $\mathrm{N}$ uptake in leaves (11.62 $\mathrm{g}$ $\mathrm{kg}^{-1}$ ) as compared to cultivar Atta-Habib which uptake $\mathrm{N}$ in leaves $\left(11.36 \mathrm{~g} \mathrm{~kg}^{-1}\right)$. The possible reason could be genetic constitution of wheat cultivars that affect nitrogen uptake in leaves. Urea coated with urease inhibitor $100 \%$ at sowing time uptake maximum $\mathrm{N}$ in leaves (15.06 $\mathrm{g} \mathrm{kg}^{-1}$ ), while minimum $\mathrm{N}$ uptake in leaves (11.44 $\mathrm{g} \mathrm{kg}^{-1}$ ) was recorded when urea coated with urease inhibitor $100 \%$ at booting stage. The ability of coated urease inhibitor $100 \%$ at sowing stage to inhibit the nutrient and release slowly which enough for longer time and protect urea from leaching could be the possible reason for maximum $\mathrm{N}$ uptake in leaves. These results agree with the findings of [22] who reported that nitrogen use efficiency had increased with use of urease inhibitor $100 \%$ at sowing stage in wheat which minimized hydrolysis and retarded nitrification process as a result uptake of $\mathrm{N}$ in leaves increased as compared when coated urease inhibitor $100 \%$ at booting stage.
$N$ uptake in grain $\left({\left.\mathrm{g} \mathrm{gg}^{-1}\right)}^{-1}\right.$

Data regarding $\mathrm{N}$ uptake in grain are presented in table 1 showed that nitrogen levels had significantly effect on $\mathrm{N}$ uptake in grain. Plots treated with $120 \mathrm{~kg} \mathrm{~N}^{-1}$ uptake more $\mathrm{N}$ in grain $\left(29.78 \mathrm{~g} \mathrm{~kg}^{-1}\right.$ ) while minimum $\mathrm{N}$ uptake in grain (18.38 $\mathrm{g} \mathrm{kg}^{-1}$ ) was recorded in control plots. These results agree with those [23] who reported that Increasing rate of nitrogen application significantly increased nitrogen uptake in grain up to $(34 \%)$ over other rates of application as well as control plots. Urea coated with urease inhibitor $100 \%$ at sowing time uptake more $\mathrm{N}$ in grain (32.68 $\mathrm{g} \mathrm{kg}^{-1}$ ), while minimum $\mathrm{N}$ uptake in grain $\left(23.69 \mathrm{~g} \mathrm{~kg}^{-1}\right)$ was recorded when urea coated with urease inhibitor $100 \%$ at booting stage. These results are in line with [24] who reported that coated urease inhibitor $100 \%$ at sowing stage increased total nitrogen recovery in plants by $22 \%$ with increased nitrogen use efficiency by $18 \%$ and reducing $\mathrm{NH}_{4}$ volatilization as a result $\mathrm{N}$ uptake in grain increased as compared urea coated with urease inhibitor $100 \%$ at booting. Cultivar Siran uptake more $\mathrm{N}$ in grain (25.15 $\left.\mathrm{g} \mathrm{kg}^{-1}\right)$ as compared to cultivar Atta-Habib which uptake minimum $\mathrm{N}$ in grain $\left(24.27 \mathrm{~g} \mathrm{~kg}^{-1}\right)$. The difference among the cultivars might be due to genetic makeup and nitrogen uptake ability. Interaction among $\mathrm{N} \times \mathrm{U} \times \mathrm{V}$ indicated in (Fig. 1) that both cultivars treated with urease inhibitor $100 \%$ at sowing stage produced uptake more $\mathrm{N}$ in grain with increasing nitrogen up to $120 \mathrm{~kg} \mathrm{ha}^{-}$ ${ }^{1}$ further increased in nitrogen slightly decrease $\mathrm{N}$ uptake in grain was recorded in both cultivars. Linear increased for $\mathrm{N}$ uptake in grain was recorded when cultivar Siran treated with $120 \mathrm{~kg}$ $\mathrm{N} \mathrm{ha}{ }^{-1}$ and coated urea with urease inhibitor $100 \%$ at sowing stage, however sharply decreased $\mathrm{N}$ uptake in grain was produced when urea coated with urease inhibitor $100 \%$ at booting stage.

$N$ in soil $\left(\mathrm{g} \mathrm{kg}^{-1}\right)$

Mean value of nitrogen levels showed in table 1 that nitrogen in soil significantly increase with increasing nitrogen level. Therefore the highest level of nitrogen $\left(150 \mathrm{~kg} \mathrm{ha}^{-1}\right)$ retained maximum $\mathrm{N}$ in soil $\left(6.90 \mathrm{~g} \mathrm{~kg}^{-1}\right)$ while lowest $\mathrm{N}$ in soil (3.01 $\mathrm{g} \mathrm{kg}^{-1}$ ) was recorded in control plot. These results are in line with the findings of [8] who reported that significantly increased nitrogen in soil with increasing nitrogen level. Plots received $140 \mathrm{~kg} \mathrm{~N} \mathrm{ha}{ }^{-1}$ increased $\mathrm{N}$ in soil $(51 \%)$ as compared with control plots. Urea coated with urease inhibitor $100 \%$ at booting time retained 
maximum $\mathrm{N}$ in soil (7.39 $\left.\mathrm{g} \mathrm{kg}^{-1}\right)$, while minimum $\mathrm{N}$ in soil $\left(5.24 \mathrm{~g} \mathrm{~kg}^{-1}\right)$ was recorded when urea coated with urease inhibitor $100 \%$ at sowing stage. The ability of urease inhibitor coated $100 \%$ at booting stage to inhibit the nutrient and release slowly which enough for longer time and protect urea from leaching could be the possible reason for increased $\mathrm{N}$ in soil. Our results also agree with the findings of [22]. Interaction among $\mathrm{N} \times \mathrm{U} \times \mathrm{V}$ indicated in (Fig.
2) that both cultivars treated with urease inhibitor $100 \%$ at booting stage retained maximum $\mathrm{N}$ in soil with increasing nitrogen. Linear increased for $\mathrm{N}$ in soil was recorded when cultivar Siran treated with $150 \mathrm{~kg} \mathrm{~N} \mathrm{ha}^{-1}$ and coated urea with urease inhibitor $100 \%$ at booting stage, however sharply decreased $\mathrm{N}$ in soil was produced when urea coated with urease inhibitor $100 \%$ at sowing stage.

Table I. Nitrogen uptake in roots $\left(\mathrm{g} \mathrm{kg}^{-1}\right)$, Nitrogen uptake in stem $\left(\mathrm{g} \mathrm{kg}^{-1}\right)$, Nitrogen uptake in leaves $\left(\mathrm{g} \mathrm{kg}^{-}\right.$ $\left.{ }^{1}\right)$, Nitrogen uptake in grain $\left(\mathrm{g} \mathrm{kg}^{-1}\right)$ and Nitrogen in soil $\left(\mathrm{g} \mathrm{kg}^{-1}\right)$ of wheat cultivars as affected by Urease inhibitor stages and Nitrogen levels.

\begin{tabular}{|c|c|c|c|c|c|}
\hline \multirow{2}{*}{ Treatment } & Roots & Stem & Leaves & Grain & $\mathrm{N}$ in soil $\left(\mathrm{g} \mathrm{kg}^{-1}\right)$ \\
\hline & \multicolumn{5}{|c|}{---------Nitrogen uptake $\left(\mathrm{g} \mathrm{kg}^{-1}\right)$--------- } \\
\hline \multicolumn{6}{|c|}{ Nitrogen $(\mathrm{N})\left(\mathrm{kg} \mathrm{ha}^{-1}\right)$} \\
\hline 0 & $4.54 \mathrm{~d}$ & $3.54 \mathrm{~d}$ & $8.50 \mathrm{~d}$ & $18.38 \mathrm{~d}$ & $3.01 \mathrm{~d}$ \\
\hline 60 & $8.65 c$ & $6.60 \mathrm{c}$ & $12.82 b$ & $26.05 c$ & $6.04 \mathrm{~b}$ \\
\hline 120 & $9.90 \mathrm{a}$ & $8.94 a$ & $14.03 \mathrm{a}$ & $29.78 \mathrm{a}$ & $6.10 \mathrm{~b}$ \\
\hline 150 & $9.42 \mathrm{~b}$ & $7.76 \mathrm{~b}$ & $13.59 \mathrm{a}$ & $28.30 b$ & $6.90 \mathrm{a}$ \\
\hline $\operatorname{LSD}(0.05)$ & 0.34 & 0.30 & 1.25 & 0.94 & 0.45 \\
\hline \multicolumn{6}{|c|}{ Urease inhibitor Stages } \\
\hline Sowing & $11.40 \mathrm{a}$ & $9.95 \mathrm{a}$ & $15.06 \mathrm{a}$ & $32.68 \mathrm{a}$ & $5.24 \mathrm{c}$ \\
\hline (Sowing + Booting) & $9.50 \mathrm{~b}$ & $8.00 \mathrm{~b}$ & $13.95 b$ & $27.75 b$ & $6.42 b$ \\
\hline Booting & $7.07 \mathrm{c}$ & $5.34 \mathrm{c}$ & $11.44 \mathrm{c}$ & $23.69 \mathrm{c}$ & $7.39 \mathrm{a}$ \\
\hline LSD $(0.05)$ & 0.34 & 0.30 & 1.25 & 0.94 & 0.45 \\
\hline \multicolumn{6}{|l|}{ Cultivars (V) } \\
\hline Siran & $7.04 \mathrm{a}$ & $5.86 a$ & $11.62 \mathrm{a}$ & $25.15 a$ & 5.20 \\
\hline Atta Habib & $6.82 b$ & $5.45 \mathrm{~b}$ & $11.36 \mathrm{~b}$ & $24.27 \mathrm{~b}$ & 5.16 \\
\hline \multicolumn{6}{|l|}{ Interaction } \\
\hline $\mathrm{N} \times \mathrm{U}$ & ns & ns & ns & ns & ns \\
\hline$U \times \mathrm{V}$ & ns & ns & ns & ns & ns \\
\hline $\mathrm{N}$ x V & ns & ns & ns & ns & ns \\
\hline $\mathrm{N} \times \mathrm{Ux} \mathrm{V}$ & ns & ns & ns & $*$ & $*$ \\
\hline
\end{tabular}

Means in the same category followed by different letters are significantly different at $\mathrm{P} \leq 0.05$ levels. $\mathrm{ns}=$ non-significant $*=$ significant 

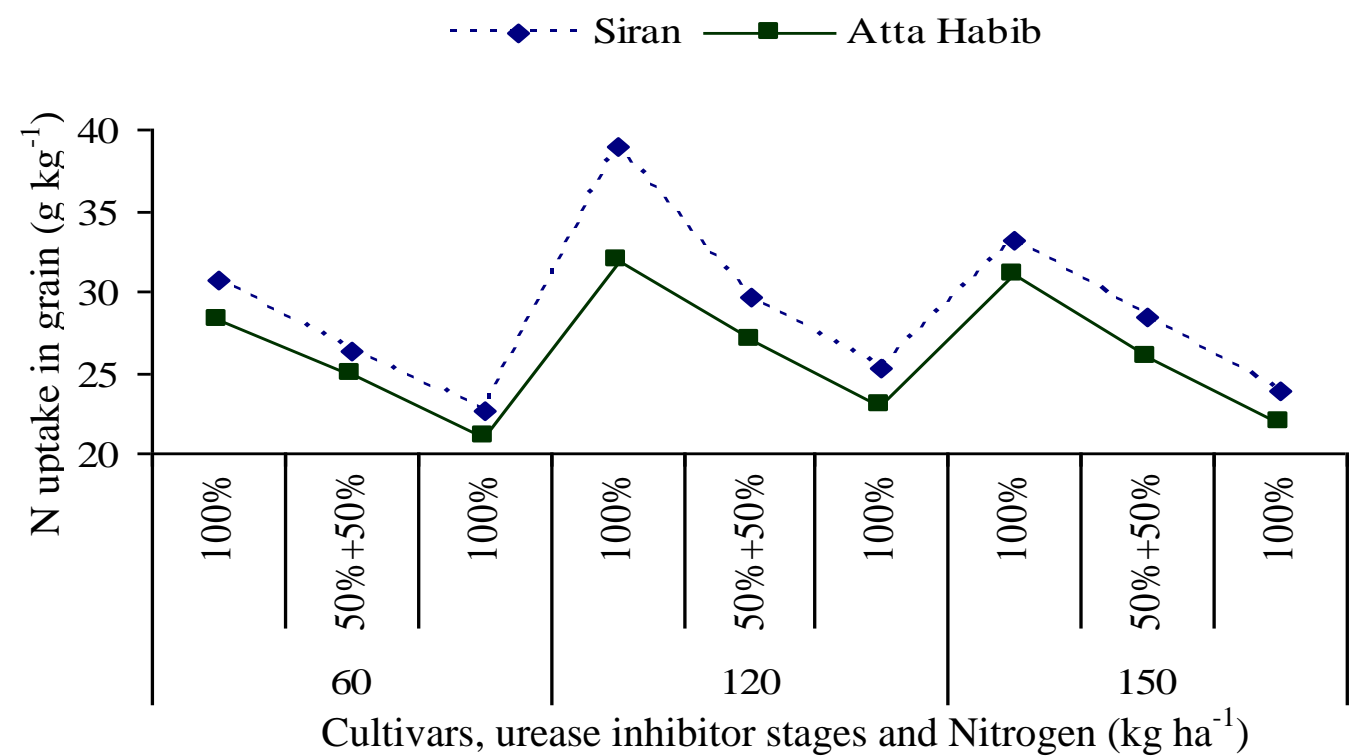

Fig. 1. $\mathrm{N}$ uptake in grain of wheat as affected by urease inhibitor stages, cultivars and nitrogen levels.

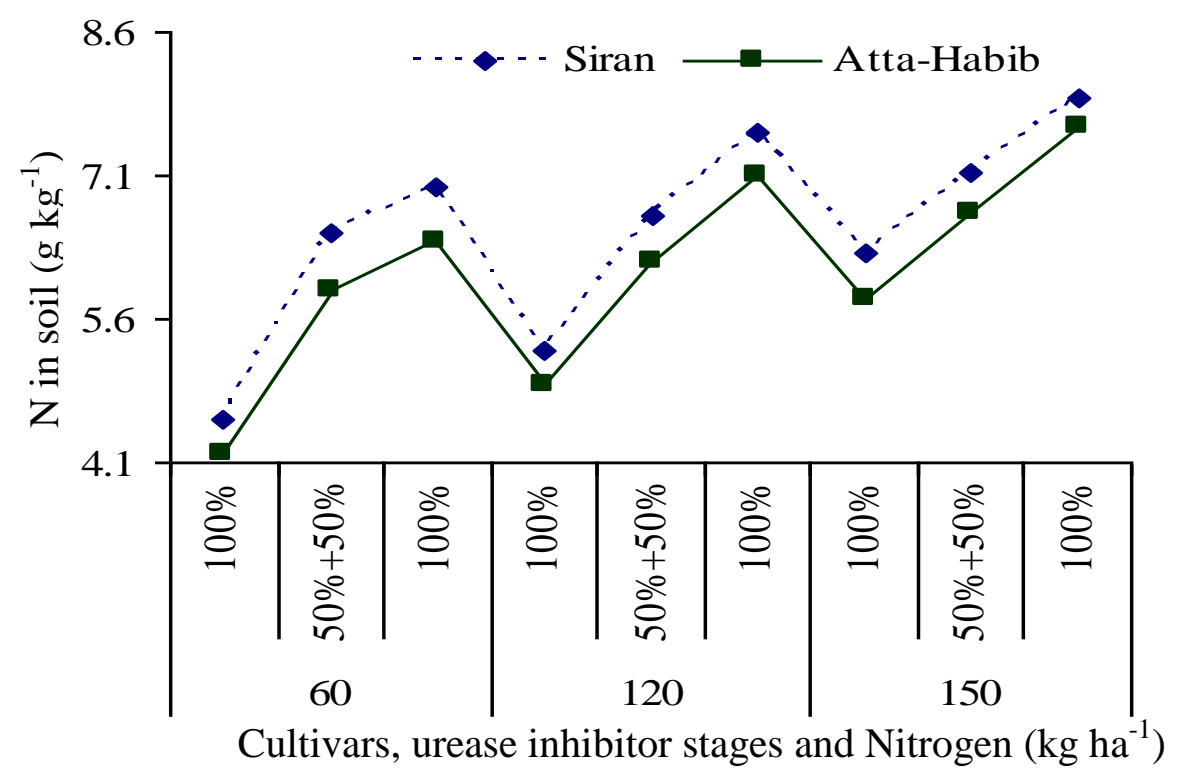

Fig. 2. $\mathrm{N}$ in soil of wheat as affected by urease inhibitor stages, cultivars and nitrogen levels

\section{Conclusion and recommendations}

The results obtained from the present study indicated that application of $\mathrm{N}$ had improved nitrogen uptake in roots, stem, leaves and grain of wheat cultivar Siran compared to control. In general, urea coated with urease inhibitor $100 \%$ at sowing stage uptake more nitrogen $\left(\mathrm{g} \mathrm{kg}^{-1}\right)$ as compared with $50 \%$ sowing stage $+50 \%$ booting stage and $100 \%$ at booting stage. Keeping in view the above facts nitrogen uptake of wheat cultivar Siran can be increased by using nitrogen at the rate of $120 \mathrm{~kg} \mathrm{ha}^{-1}$ and coated urea with urease inhibitor $100 \%$ at sowing stage in agroclimatic condition of Peshawar valley.

\section{References}

1. Arzadun, M.J., J.I. Arroquy, H.E. Laborde and R.E. Brevedan. (2006). Effect of planting dates, clipping height and cultivars on forage and grain yield of winter wheat. Agron. J. 98: 12741279.

2. Krenzer, E. G. (2000). Wheat is a forage. P 27-30 in T.A. Royer and E.G. Krenzer (ed). 
Wheat management in Oklahoma. Oklahoma crop. Ext. Serv. and Oklahoma Agric. Exp. St. E831.

3. MINFA. 2012. Ministry for food Agriculture, Agriculture Statistics of Pakistan. Govt. of Pak, Economic Wing, Islamabad.

4. Mosier, A.R. (2001). Exchange of gaseous nitrogen compound between agricultural systems and the atmosphere. Plant and Soil 228:17-27.

5. Bouwman, A.F., L.J. Boumans, and N.H. Batjes. (2002). Estimation of global NH3 volatilization loss from synthetic fertilizers and animal manure applied to arable lands and grasslands. Global Biogeochem. Cycles 16: 8-1 8-14 and the atmosphere. Plant and Soil 228:1727.

6. Black, A.S., R.R. Sherlock, and N.P. Smith. (1987). Effect of timing of simulated rainfall on ammonia volatilization from urea, applied to soil of varying moisture-content. J Soil. Sci. 38:679687.

7. Ahmed, O.H., S. Rosliza, N.M.Ab. Majid and M.B Jalloh. (2012). Effect of N, P and K humates on dry matter of wheat and soil $\mathrm{pH}$, exchangeable ammonium and available nitrate

A. J. Bio. 11(40): 9566-9571.

8. Zaman, M., S. Saggarb, J. D. Blennerhassetta and J. Singh. (2009). Effect of urease inhibitor and nitrification inhibitors on $\mathrm{N}$ transformation, gaseous emission of ammonia and nitrous oxide, pasture yield and nitrogen uptake in grazed pasture system. Soil Biol. Biochem. 41(6):12701280.

9. Limon-Ortega, A., K.D. Sayre and C.A. Francis. (2000). Wheat nitrogen use efficiency in a bed planting system in northwest Mexico. Agron. J., 92: 303-308.

10. Tran, T.S. and G. Tremblay (2000). Recovery of N-15-labeled fertilizer by spring bread wheat at different $\mathrm{N}$ rates and application times. Can. J. Soil Sci., 80: 533-539.

11. Alcoz, M.M., F.M. Hons and V.A. Haby. (1993). Nitrogen fertilization timing effect on wheat production, nitrogen uptake efficiency and residual soil nitrogen. Agron. J., 85: 1198-1203.

12. Spiertz, J. De Vos, and Hole L. (1984). The role of nitrogen in the yield formation of cereals, especially of winter wheat. In: the Proceedings of Cereal Production, Royal Dublin Society, and Bultworths.

13. Hogan, M. E., I. E. Swift, and J. Done. (1983). Urease inhibitor assay and ammonia release from leaf tissue. Photochemistry. 22(3): 663-667.

14. Amanullah, M. Zakirullah and S. K. Khalil. (2010). Timing and rate of phosphorus application influence maize phenology, yield and profitability in Northwest Pakistan. Int. J. Plant Prod. 4 (4):283-294.

15. Halvorson A.D., D. C. Nielsen, C. A. Reule. (2004). Nitrogen fertilization and rotation effects on no-till dryland wheat production. Agron J 96: 1196-1201.

16. Steel, R.G.D. and Torrie, J.H. 1980. Analysis of Covariance. In: Principles and Procedures of Statistics. a Biometrical Approach. $2^{\text {nd }}$ Ed., McGraw-Hill New York. 401-437.

17. Khan, A., M.T. Jan, M. Arif, K.B. Marwat, and A. Jan (2008). Phenology and crop stand of wheat affected by nitrogen sources subjected to different tillage practices. Pak. J. Bot. 40:11031112.

18. Pereira, H. S., A. F. Leao, A. Verginassi and M. Aurellio (2009). Ammonia volatilization of urea in the out-of-season corn. Revista Brasileira Ciencia do Solo. 33:1685-1694.

19. Deldon, A. V. (2001). Yield and growth components of potato and wheat under organic $\mathrm{N}$ management. Agron. J. 93:1370-1385.

20. Chen, L., P.Boeckx, L. Zhou, O.V. Cleemput and R. Li. (1998). Effect of hydroquinone, dicyandiamide and encapsulated calcium carbite on urea-N uptake by spring wheat, soil mineral $\mathrm{N}$ content and $\mathrm{N}_{2} \mathrm{O}$ emission. Soil Use and Management. 14:230-233.

21. Nad, B. K., J. J. Purakayastha and D. V. Singh. (2001). Nitrogen and urease inhibitor relation in effecting yield and quality of cereals and oil seed crops. Scientific World J. 11(2):3040.

22. Sheng, L. Z and C. Lin. (2007). Effects in methods of urea application combined with urease inhibitor inhibitors under drip irrigation on maize. Plant Nut. Fert. Sci. 104-105.

23. Awasti, U.D. and S. Bham. (1994). Physiological response of barley genotypes to nitrogen levels under moisture scares condition of light textured soils of Central Utter Paredash. Indian J. Plant Physiology 37(1):32-34.

24. Zhang, L., Z. Wu, Y. Jiang, L. Chen, Y. Song, L. Wang, J. Xie and X. Ma. (2010). Fate of applied urea ${ }^{15} \mathrm{~N}$ in a soil-maize system as affected by urease inhibitor inhibitor. Plant and soil Enviroment. 56(1):8-15. 